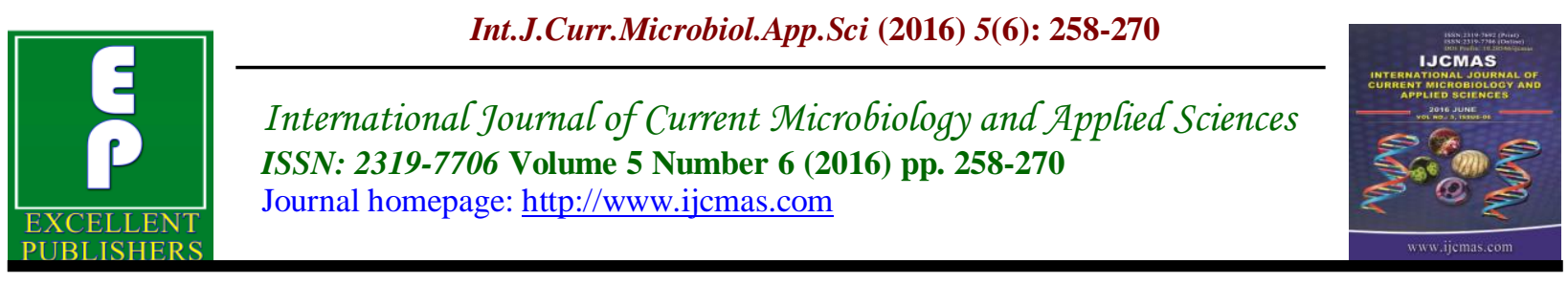

Original Research Article

http://dx.doi.org/10.20546/ijcmas.2016.506.029

\title{
Ethnobotanical Survey of Plants Used in the Treatment of Diabetes Mellitus in Tabuk Region, Saudi Arabia
}

\author{
Amal, M. Fakhry and Masarrat, M.M. Migahid* \\ Botany and Microbiology Department, Faculty of Science and Biological and Geological \\ Sciences Department, Faculty of Education, Alexandria University, Alexandria, Egypt \\ *Corresponding author
}

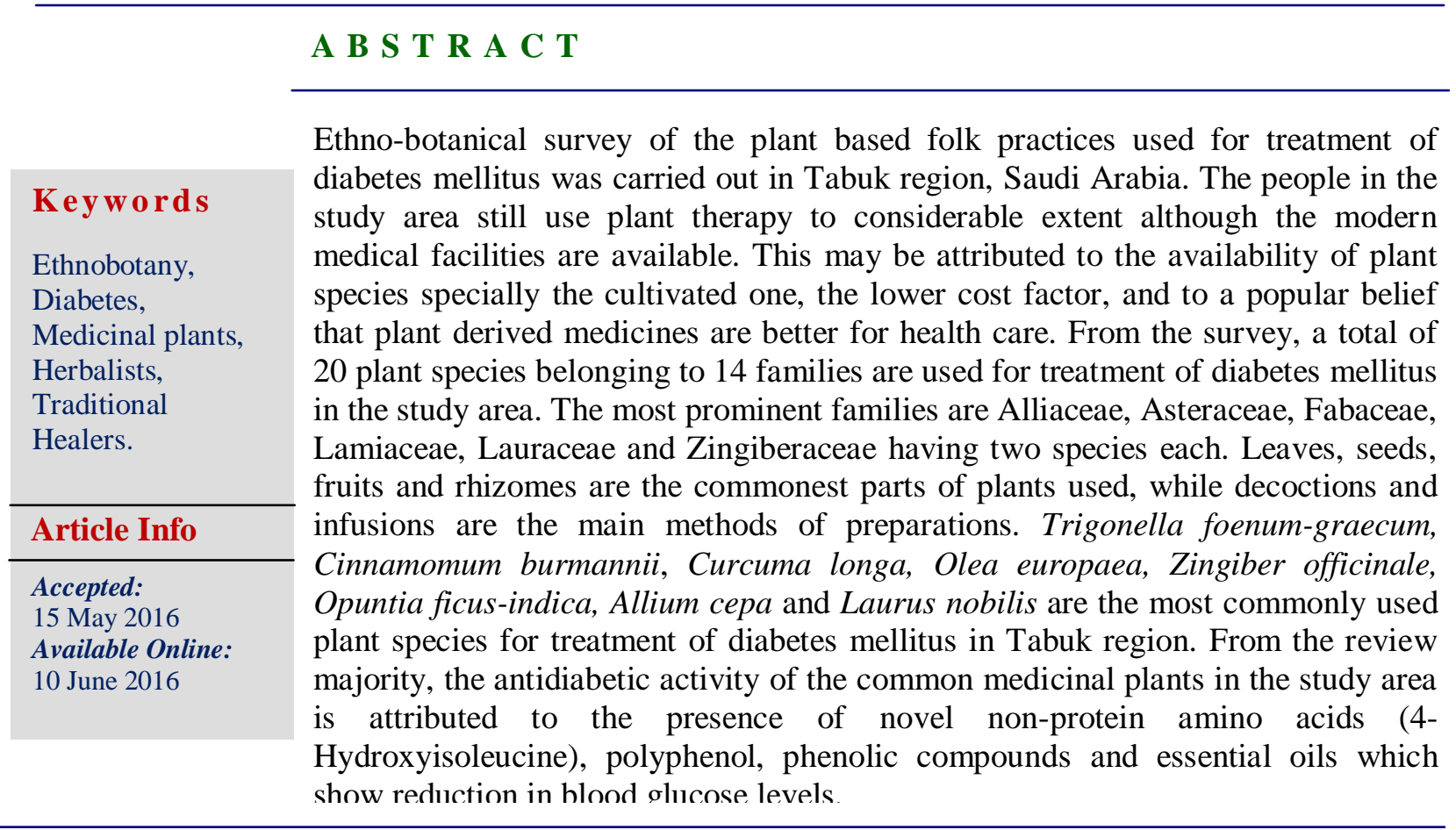

\section{Introduction}

According to the World Health Organization (WHO, 1976) defined medicinal plant as any plant which in one or more of its organ contain substance that can be used for therapeutic purposes or used as precursors for the synthesis of useful drugs. Diabetes mellitus (DM) is a major worldwide serious disease in all parts of the world. DM is a metabolic disorder characterized by the presence of hyperglycemia due to deficiency of the insulin secretion leading to high blood glucose level in people suffering from diabetes (Ponnusamy et al., 2011) or due to defective insulin action or both (Mitra, 2008). There has been an explosion in the number of people suffering from the disease. Worldwide 371 million people are affected and by the year 2035 the number is predicted to go up to almost 600 million (Zimmet et al., 2014). Throughout history, man used various natural materials as a 
remedy for various diseases and Plants play a central role in folk medicine in considerable proportions of world's populations. Human bodies possess enzymatic and non-enzymatic anti-oxidative mechanisms which minimize the generation of reactive oxygen species, responsible for many degenerative diseases including diabetes (Patel et al., 2011). Ethno pharmacological research is considered crucial in the development and discovery of new drugs from natural sources (Soejarto and Fransworth, 1989; Fransworth, 1985). There are numerous medicinal plants in Saudi Arabia for treatment of many diseases. The deserts and mountains of Saudi Arabia are covered with more than 2500 plant species most of which are noted for their uses as medicinal herbs. Beside the native plant species, a considerable number of imported plant species are used in folk medicine in Saudi Arabia. However, searching for new antidiabetic drugs from natural plants is still attractive because they contain substances which demonstrated as alternative and safe drugs for DM. Most of plants contain glycosides, alkaloids, terpenoids, flavonoids, carotenoids, etc., that are frequently implicated as having antidiabetic effect (Malviya et al., 2010). Many traditional healers and herbalists in Tabuk region of Saudi Arabia have been treating diabetic patients for many years using various medicinal plant species. Despite the long history of treating diabetes in Tabuk region using herbal remedies, the knowledge and experience of these herbalists have not been scientifically documented.

\section{Materials and Methods}

The survey was carried out in different areas of Tabuk region, Saudi Arabia throughout February to May 2015. It is located along the north-west coast of the country, facing Egypt across the Red Sea (Figure 1). It covers an area of 146,072 square kilometer and has a population of 791, 595 (2010). The region is also known for its variety of flora and fauna, and diverse of natural habitats like sandy deserts, hills and mountains of unique rock formations. To gather enough information about the plant species, recipes, their local names, mode of administration and dosage. So, some herbalists, traditional healers and rural dwellers were consulted and interviewed with the aid of questionnaires designed precisely by the researchers. A great number of selected informants (different ages) that had lived most of their life in Tabuk. The interviews were carried out personally to gather information and herbarium specimens of medicinal herbs of typical effective impacts in treating diabetes when used. The information was mostly provided by adult individuals (65\% men and $25 \%$ women) while the young people (20-35 years old) percentage was $10 \%$. The plants were initially identified by their vernacular names through consultations with the local people. Scientific identification of the plant species and families was done by the author according to the Flora of Saudi Arabia (Migahid, 1996), Wild Flowers of Saudi Arabia (Collenette, 1999) and confirmed by Indigenous Knowledge (IK) system. The most important medicinal compounds were collected from different literatures (Rashmi and Rahul, 2011; Al-Dhubiab, 2012; Sawant and Godghate, 2013; Bharat et al., 2005; Bock et al., 2013; Hasan et al., 2012; JoseAlberto et al., 2009; Kumari et al., 1995; Basak and Candan 2013). Ethical approval for this study was obtained from the headmen of the studied areas

\section{Results and Discussion}

Plants identified in this study have been tested by the herbalists and according to them they are quite efficacious. A total of 20 
plant species belonging to 14 different families were described from the survey in Table 1. Traditional healers used different methods for preparing drugs. This mainly relies on the specific properties of the plants and that of desired extract. The methods of drug preparation, dosage and route of administration of medicinal plants obtained during this study are enumerated in Table 1. Decoctions and infusions are the most frequently methods of preparation. It is also noted that some plants were prepared using more than one method. The number of species as \% from total frequently used in each family was represented in Figure 2. Alliaceae, Asteraceae, Fabaceae, Lamiaceae, Lauraceae and Zingiberaceae are the most prominent having two species each (10\%). Other reported families were represented by one species each $(5 \%)$.

Analysis of the growth forms of the recorded medicinal plants (Figure 3) revealed that different herbs (perennial, annual and biennial) constituted the largest number or proportion being represented by 11 species $(55 \%)$ followed by trees 6 species $(30 \%)$ while different shrubs and subshrub by 3 species (15\%). Different parts of the plants were used in the treatment of diabetes of the study plants as showed in Figure 4. The most frequently plant parts used was the leaves (35\%) followed by seeds (20\%), fruits $(15 \%)$ and rhizomes $(10 \%)$.

The studied species based on the degree of usage $\%$ could be categorized into 6 categories (Figure 5). The reported medicinal plants as reported by informants revealed that Trigonella foenum-graecum, Cinnamomum burmannii, Curcuma longa, Olea europaea, Zingiber officinale, Opuntia ficus-indica, Allium cepa and Laurus nobilis are the most prominent species in the recipes and frequently used by traditional healers for remedy preparations (Figure 5).
For the most commonly used plant species in the study area, the main phytochemical compounds identified in references to be effective in the treatment of diabetes mellitus were presented in Table 2. It is obvious from the collected information that phenolic compounds could represent the main effective group of secondary metabolites in the treatment of diabetes mellitus and in managing the effects of diabetic complications. We also noted that there is more active compounds in the same family such as in family Lauraceae which represented by Cinnamomum burmannii and Laurus nobilis.

Diabetes mellitus is a major global health problem worldwide due to a metabolic disorder caused by abnormality of carbohydrate metabolism which is related to low blood insulin level or insensitivity of target organs to insulin (Maiti et al., 2004). A considerable number (20) of medicinal plants used by local communities in Tabuk region to treat diabetes mellitus have been documented throughout the present study. The collected information indicated to the depth of local indigenous knowledge of medicinal plants and their application in the study area. The majority of the recorded medicinal plants (16 species represent $80 \%$ ) are cultivated species and most of them are imported from other countries to be used as spice in the kitchen. Only 4 species $(20 \%)$ are belonging to the wild flora of Saudi Arabia and was recorded at the desert habitats (Collenette, 1999).

The present study revealed that medicinal plants still play a vital role in the primary health care for the people in the study area. During the survey, it was observed that more than $60 \%$ of the total number of people questioned regularly used medicinal plants for many ailments, including diabetes. The most widely used plant remedies by people 
of Tabuk region were obtained from cultivated herbs which constitute the highest category of 11 species (55\%). This may be due to their availability but those natural medicinal plants in the study area were mainly threatened by anthropogenic and natural factors. Most of the plants which were reported by the informants in the study area are Trigonella foenum-graecum, Cinnamomum burmannii, Curcuma longa, Olea europaea, Zingiber officinale, Opuntia ficus-indica, Allium cepa and Laurus nobilis. Some studied species are also used for treating diabetes problems in some parts of the country and elsewhere (El-Ghazali et al., 2006; Bahmani et al., 2014). The present study indicated that leaves, seeds, fruits and rhizomes are the commonest used parts of plant, while decoctions and infusions are the main methods of preparations. The informants in the study area reported that Fenugreek (Trigonella foenum-graecum) attained the highest usable percentage followed by Cinnamomum burmannii. Rashmi and Rahul (2011) confirmed the vital role of Trigonella foenum-graecum on diabetes due to the insulinotrophi and antidiabetic properties which have been associated with the amino acid 4hydroxyisoleucene that occurs in fenugreek by about $55 \%$. Also, their studies in vitro have indicated that this amino acid causes direct pancreatic B cells stimulation. Delayed gastric emptying and inhibition of glucose transport have been postulated as possible mechanisms. However, AlDhubiab (2012) found that Cinnamon sticks contain a phenolic compound named cinnamaldehyde $(65-80 \%)$ which play an important role in lowering blood sugar. Polansky and Anderson (2007) suggested that Cinnamomum burmannii possesses higher potential to enhance the levels of proteins involved in insulin signaling, glucose transport, and anti-inflammatory lanti-angiogenesis response. While
Tjandrawinata et al. (2011) found that herbal extract from $C$. burmannii could be used as an insulin resistance reducer, syndrome $\mathrm{X}$ normalizer, pre-diabetes and type 2 diabetes treatments.

The yellow spice made from the rhizomes of Curcuma longa contains a fat soluble, polyphenolic pigments known as Curcuminoids (Sawant and Godghate, 2013). Curcumin, may constitute 2 to $8 \%$ of the spice can be derived from $C$. longa by ethanol extraction (Bharat et al. 2005). A long-term study on healthy subject revealed no changes in fasting plasma glucose or lipid levels when $2.8 \mathrm{~g}$ turmeric was given to the subjects daily for four weeks (Tang et al., 2008). Diabetic rats given curcumin showed a significant reduction in renal dysfunction and oxidative stress (Sharma et al., 2006), which may indicate that curcumin has a protective role against diabetic nephropathy. The results of Wickenberg et al. (2010) indicate that $C$. longa may have an effect on insulin secretion.

The dried leaves of Olea europaea contain minimum $5 \%$ of oleuropein (De Bock et al., 2013). Olive plant leaves have been used for centuries in folk medicine to treat diabetes, but there are very limited data examining the effects of olive polyphenols on glucose homeostasis in humans (De Bock et al., 2013). Kaeidi et al., (2011) conclude that olive leaf extract inhibits high glucoseinduced neural damage and suppresses diabetes-induced thermal hyperalgesia. The study also suggested that mechanisms of these effects may be due, at least in part, to reduce neuronal apoptosis and suggest therapeutic potential of olive leaf extract in attenuation of diabetic neuropathic pain. De Bock et al., (2013) found that olive leaf extract supplementation is associated with a reduction in the glucose and insulin excursion after oral glucose challenge, 
suggesting an improvement in both pancreatic b-cell function and insulin sensitivity.

The major identified components in the rhizome of Zingiber officinale from terpene are sesquiterpene hydrocarbons and phenolic compounds which are gingerol and shogaol (Hassan., 2012). Ojewole (2006) found that oral administration of ethanol extract of ginger to STZ et al treated-type 1 diabetic rat significantly decrease fasting blood glucose level. Al-Amin et al., (2006) indicate that raw ginger possesses hypolycaemic, hypocholesterlaemic and hypolipidaemic potential. Additionally, raw ginger is effective in reversing the diabetic proteinuring observed in the diabetic rats. Jafri et al., (2010) also found that ginger extract has hypoglycemic effect on diabetic rats. Mahluji et al., (2013) found that ginger supplementation improved insulin sensitivity and some fractions of lipid profile in diabetic patients (type 2). Mahluji et al., (2013) and Al-Amin et al., (2006) suggested that ginger may be of great value in managing effects of diabetic complications in human.

Table.1 Medicinal plants used by the traditional healers in the treatment of diabetes in Tabuk region, Saudi Arabia

\begin{tabular}{|c|c|c|c|c|c|}
\hline Family & Botanical name & $\begin{array}{l}\text { Vernacular } \\
\text { Name }\end{array}$ & Life form & $\begin{array}{l}\text { parts } \\
\text { used }\end{array}$ & Preparation \\
\hline \multirow[t]{2}{*}{ Alliaceae } & Allium cepa L. & Basal & $\begin{array}{l}\text { Perennial } \\
\text { herb }\end{array}$ & Bulb & $\begin{array}{l}\text {-Bulbs are carefully washed, cut into pieces and } \\
\text { eaten with salad in the morning ( breakfast) } \\
\text {-Bulbs are crushed and the crude extract taken } \\
\text { orally when needed. }\end{array}$ \\
\hline & $\begin{array}{l}\text { Allium sativum } \\
\text { L. }\end{array}$ & Thoum & $\begin{array}{l}\text { Perennial } \\
\text { herb }\end{array}$ & Bulbuls & $\begin{array}{l}\text {-One bulbul is taken orally early in the morning } \\
\text { with yogurt before breakfast. }\end{array}$ \\
\hline Apiaceae & $\begin{array}{l}\text { Petroselinum } \\
\text { crispum (Mill.) } \\
\text { Fuss }\end{array}$ & Bagdonis & $\begin{array}{l}\text { Biennial } \\
\text { herb }\end{array}$ & Leaves & $\begin{array}{l}\text {-Infusion of leaves are prepared by macerating it } \\
\text { into adequate amount of hot water.one glassful is } \\
\text { taken daily after each meal. }\end{array}$ \\
\hline \multirow[t]{2}{*}{ Asteraceae } & $\begin{array}{l}\text { Achillea } \\
\text { fragrantisma } \\
\text { (Forssk) Sch. } \\
\text { Bip }\end{array}$ & Gaysoom & $\begin{array}{l}\text { Perennial } \\
\text { herb }\end{array}$ & Leaves & $\begin{array}{l}\text {-Infusion of leaves is prepared by macerating it } \\
\text { into adequate amount of hot water. One glassful is } \\
\text { taken daily. }\end{array}$ \\
\hline & $\begin{array}{l}\text { Artemisia } \\
\text { herba-alba } \\
\text { Asso }\end{array}$ & Sheeh & Subshrub & Leaves & $\begin{array}{l}\text {-Decoction of leaves is prepared by boiling it into } \\
\text { adequate amount of water. One glassful is taken } \\
\text { daily early in the morning. }\end{array}$ \\
\hline Cactaceae & $\begin{array}{l}\text { Opuntia } \\
\text { ficus-indica } \\
\text { (L.) Mill }\end{array}$ & $\begin{array}{l}\text { Teen } \\
\text { Shooky }\end{array}$ & $\begin{array}{l}\text { Succulent } \\
\text { shrub }\end{array}$ & $\begin{array}{l}\text { Stems \& } \\
\text { Fruits }\end{array}$ & $\begin{array}{l}\text { - Decoction of fruits is prepared by boiling it into } \\
\text { adequate amount of water. One glassful is taken } \\
\text { before meals twice daily. } \\
\text {-Succulent stems are macerating in cold or hot } \\
\text { water for } 12 \text { hours. One glassful is taken daily in } \\
\text { the morning. }\end{array}$ \\
\hline \multirow[b]{2}{*}{ Fabaceae } & $\begin{array}{l}\text { Lupinus albus } \\
\text { L. }\end{array}$ & Termis & $\begin{array}{l}\text { Annual } \\
\text { herb }\end{array}$ & Seeds & $\begin{array}{l}\text {-Seeds are macerating in cold or hot water for one } \\
\text { hour. One glassful is taken daily in the morning. }\end{array}$ \\
\hline & $\begin{array}{l}\text { Trigonella } \\
\text { foenum- } \\
\text { graecum } \mathrm{L} .\end{array}$ & Helbah & $\begin{array}{l}\text { Annual } \\
\text { herb }\end{array}$ & Seeds & $\begin{array}{l}\text { - Decoction of seeds is prepared by boiling it into } \\
\text { adequate amount of water. One glassful is taken at } \\
\text { night before sleeping. } \\
\text {-Seeds are carefully washed, dried and powdered. } \\
\text { One spoonful is taken daily early in the morning. }\end{array}$ \\
\hline
\end{tabular}




\begin{tabular}{|c|c|c|c|c|c|}
\hline \multirow{2}{*}{ Lamiaceae } & $\begin{array}{l}\text { Teucrium } \\
\text { polium } \mathrm{L} .\end{array}$ & Geaadah & $\begin{array}{l}\text { Perennial } \\
\text { herb }\end{array}$ & Leaves & $\begin{array}{l}\text {-Decoction of leaves is prepared by boiling it into } \\
\text { adequate amount of water. One glassful is taken } \\
\text { daily. }\end{array}$ \\
\hline & $\begin{array}{l}\text { Salvia } \\
\text { officinalis L. }\end{array}$ & Maramyah & Shrub & Leaves & $\begin{array}{l}\text {-Decoction of leaves is prepared by boiling it into } \\
\text { adequate amount of water. One glassful is taken } \\
\text { daily early in the morning before breakfast. }\end{array}$ \\
\hline \multirow[t]{2}{*}{ Lauraceae } & $\begin{array}{l}\text { Cinnamomum } \\
\text { burmannii } \\
\text { (NEES\&Th. } \\
\text { Nees) Nees ex } \\
\text { Blume } \\
\end{array}$ & Gerfah & Tree & Bark & $\begin{array}{l}\text {-Decoction of bark is prepared by boiling it into } \\
\text { adequate amount of water. One glassful is taken } \\
\text { daily late in the evening. }\end{array}$ \\
\hline & $\begin{array}{l}\text { Laurus nobilis } \\
\text { L. }\end{array}$ & Ghar & Tree & Leaves & $\begin{array}{l}\text {-Leaves are air dried and then ground. One } \\
\text { spoonful is macerating in glassful hot water or tea } \\
\text { and taken orally once daily. }\end{array}$ \\
\hline Lythraceae & $\begin{array}{l}\text { Punica } \\
\text { granatum L. }\end{array}$ & Roman & Tree & Fruit & $\begin{array}{l}\text {-Carefully wash the pericarp, cut into pieces, air- } \\
\text { dried and then ground. One small spoonful is } \\
\text { mixed with honey and is taken daily early in the } \\
\text { morning before breakfast. }\end{array}$ \\
\hline Myrtaceae & $\begin{array}{l}\text { Syzygium } \\
\text { aromaticum } \\
\text { (L.) Merrill \& } \\
\text { Perry }\end{array}$ & Koronfil & Tree & $\begin{array}{l}\text { Flower } \\
\text { Buds }\end{array}$ & $\begin{array}{l}\text {-Decoction of flower buds is prepared by boiling it } \\
\text { into adequate amount of water or a cup of tea. One } \\
\text { glassful is taken daily for } 30 \text { consecutive days. }\end{array}$ \\
\hline Oleaceae & $\begin{array}{l}\text { Olea } \\
\text { europaea } \mathrm{L} .\end{array}$ & Zaytoon & Tree & $\begin{array}{l}\text { Fruit } \\
\text { (oil) } \\
\& \text { leaves }\end{array}$ & $\begin{array}{l}\text {-One spoonful is taken daily mixed with meals. } \\
\text {-Decoction of leaves is prepared by boiling it into } \\
\text { adequate amount of water. One glassful is taken } \\
\text { daily. }\end{array}$ \\
\hline Pedaliaceae & $\begin{array}{l}\text { Sesamum } \\
\text { indicum } \mathrm{L} .\end{array}$ & Semsem & $\begin{array}{l}\text { Annual } \\
\text { herb }\end{array}$ & Seeds & $\begin{array}{l}\text {-One spoonful of seeds is mixed with a cup of } \\
\text { fresh milk and is taken daily in the morning. }\end{array}$ \\
\hline Ranunculaceae & $\begin{array}{l}\text { Nigella sativa } \\
\text { L. }\end{array}$ & Haba soda & $\begin{array}{l}\text { Annual } \\
\text { herb }\end{array}$ & Seeds & $\begin{array}{l}\text {-Seven seeds are taken daily in the morning. } \\
\text {-Infusion of powdered seeds is prepared by } \\
\text { macerating it into adequate amount of hot water. } \\
\text { One glassful is taken before every meal. }\end{array}$ \\
\hline Rhamnaceae & \begin{tabular}{|lr} 
Ziziphus & spina \\
christi & (L.) \\
Desf. &
\end{tabular} & Sedr & Tree & Leaves & $\begin{array}{l}\text {-Seven fresh leaves are taken daily in the morning. } \\
\text {-Leaves are air dried and then ground. One } \\
\text { spoonful is macerating in glassful cold water and } \\
\text { taken orally twice daily. }\end{array}$ \\
\hline & $\begin{array}{l}\text { Curcuma longa } \\
\text { L. }\end{array}$ & Curcum & $\begin{array}{l}\text { Perennial } \\
\text { herb }\end{array}$ & Rhizome & $\begin{array}{l}\text {-Carefully wash the rhizome, cut it into pieces, } \\
\text { air-dried and then ground. Decoction of pulverized } \\
\text { dry rhizome is prepared by boiling it into adequate } \\
\text { amount of water. One glassful is taken twice daily. }\end{array}$ \\
\hline Zingiberaceae & $\begin{array}{l}\text { Zingiber } \\
\text { officinale } \\
\text { Roscoe }\end{array}$ & Zangabil & $\begin{array}{l}\text { Perennial } \\
\text { herb }\end{array}$ & Rhizome & $\begin{array}{l}\text {-Carefully wash the rhizome, cut it into pieces, } \\
\text { air-dried and then ground. One small spoonful is } \\
\text { mixed with a cup of fresh milk or tea and is taken } \\
\text { daily in the morning. } \\
\text {-Decoction of pulverized dry rhizome is prepared } \\
\text { by boiling it into adequate amount of water. One } \\
\text { glassful is taken daily. }\end{array}$ \\
\hline
\end{tabular}


Table.2 Main Phytochemical compounds identified in the most commonly used plant species in the treatment of diabetes.

\begin{tabular}{|l|l|l|}
\hline Plant species & Phytochemical compound & References \\
\hline Trigonella foenum-graecum & 4-hydroxyisoleucene (amino acid) & Rashmi and Rahul, 2011 \\
\hline Cinnamomum burmannii & Cinnamaldehyde (phenol) & Al-Dhubiab, 2012 \\
\hline Curcuma longa & Curcumin ( polyphenol) & Sawant and Godghate, 2013; Bharat et al., 2005 \\
\hline Olea europaea & Oleuropein ( Polyphenol) & Bock et al., 2013 \\
\hline Zingiber officinale & Gengerol ( polyphenol) & Hasan et al., 2012 \\
\hline Opuntia ficus-indica & flavonoids (polyphenol) & Jose-Alberto et al., 2009 \\
\hline Allium cepa & Quercetin (phenol) & Kumari et al., 1995 \\
\hline Laurus nobilis & 1,8 - cineole ( essential oil) & Basak and Candan 2013 \\
\hline
\end{tabular}

Fig.1 Map of Saudi Arabia illustrating the geographical position of Tabuk District.

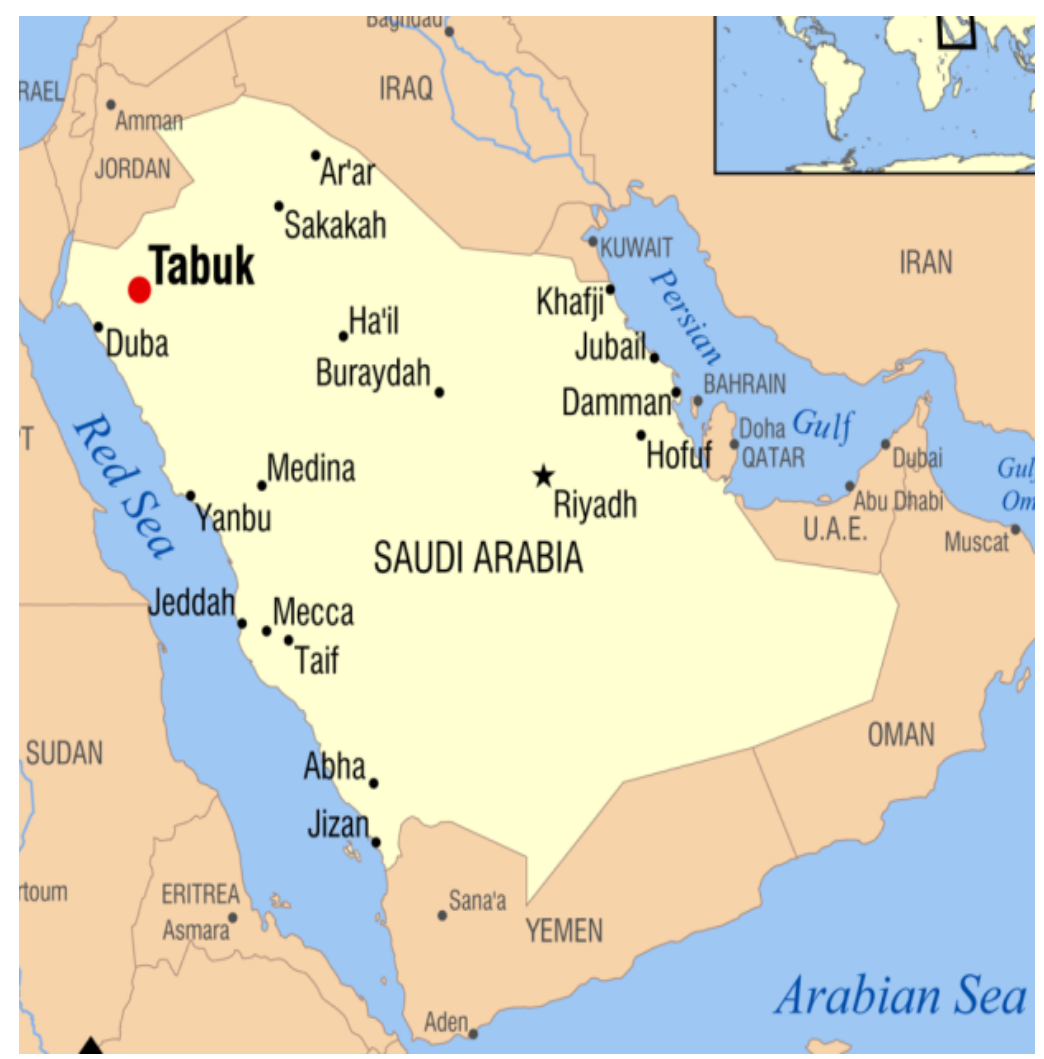


Fig.2 Percentage species distribution in the recorded families

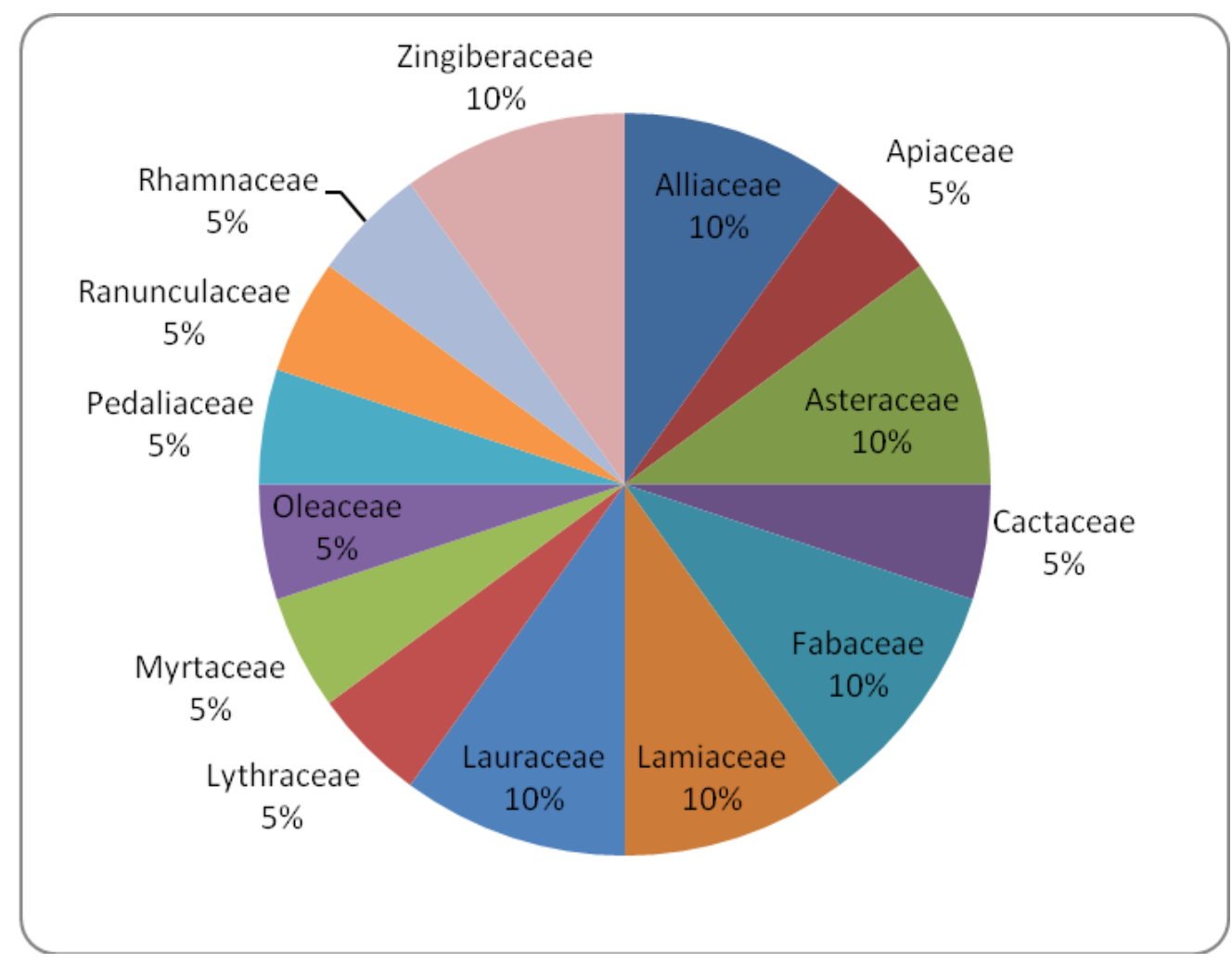

Fig.3 Percentage growth forms of the reported ethno medicinal plant species

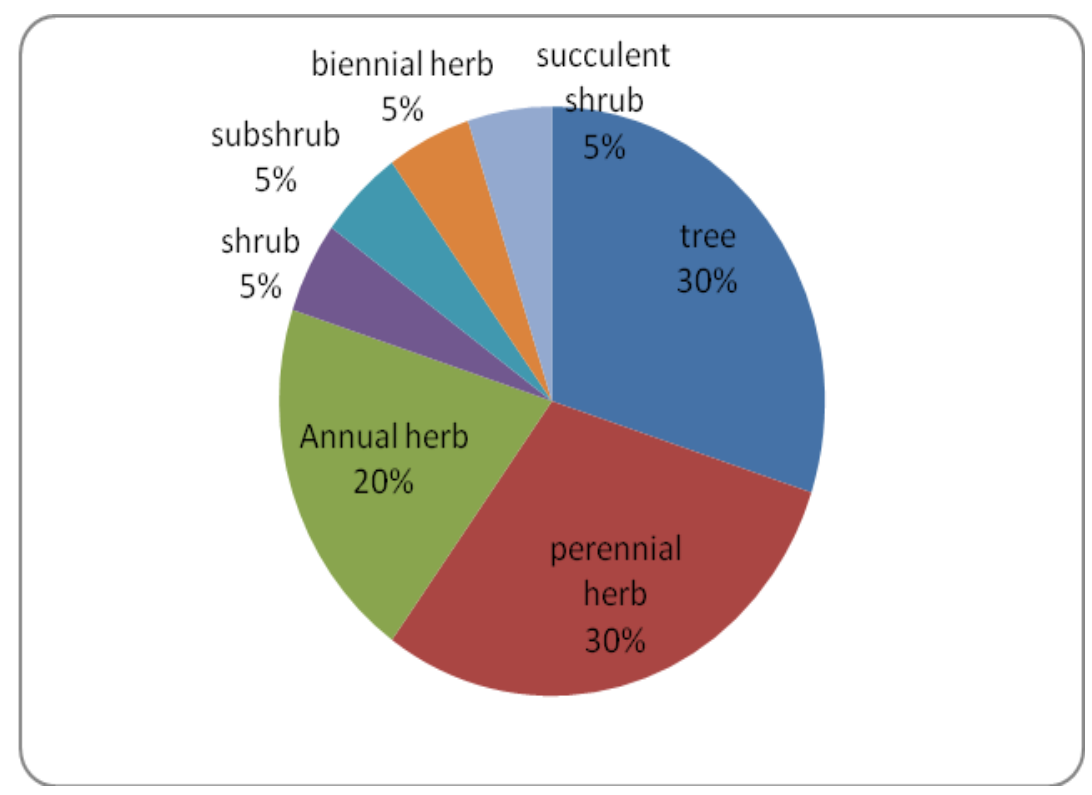


Fig.4 Percentage of plant parts used by traditional healers for remedy preparations

Bark Bulb Bulbuls $\square$ leaves $\square$ flower bud $\square$ Fruit $\square$ Rhizome $\square$ Seeds

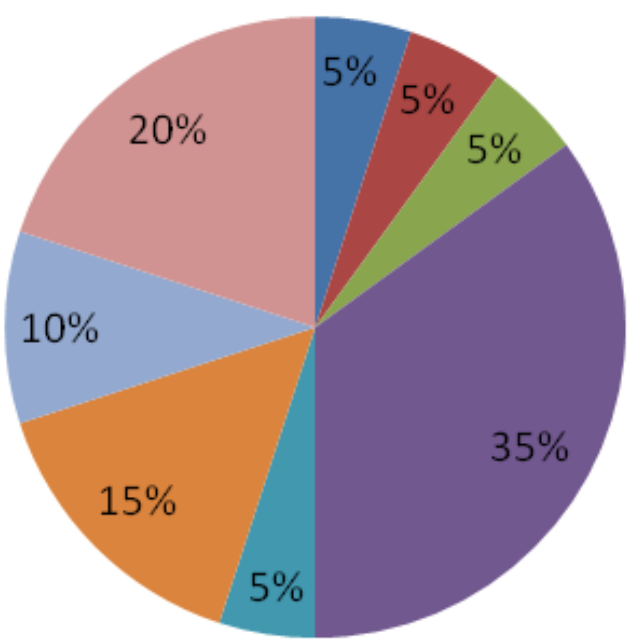

Fig.5 Categories of the reported medicinal plants based on the degree of usage \% as reported by informants.

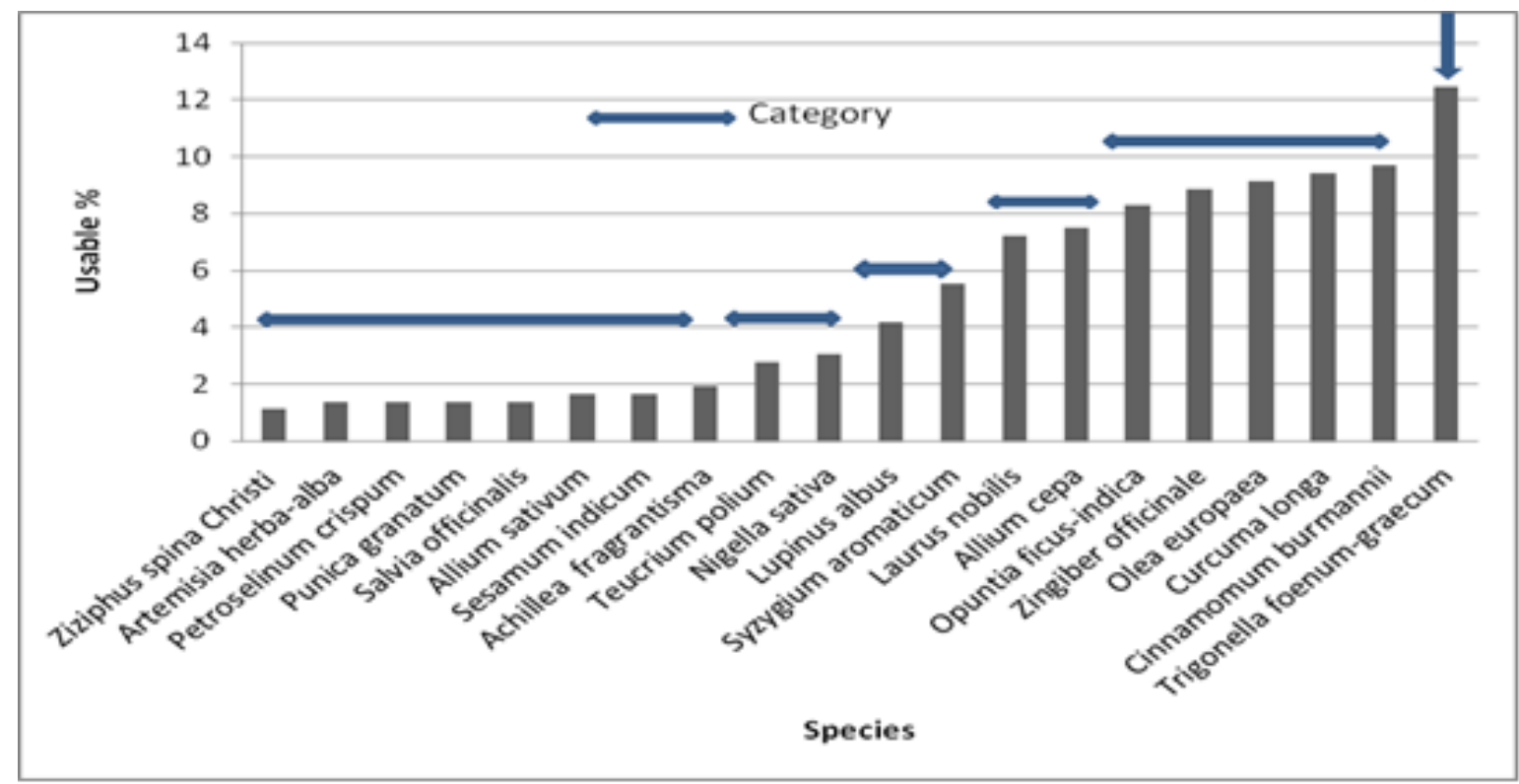

Water extract from cladodes of Opuntia ficus-indica contains polyphenols which play an important role in the glycemia regulation on the diabetic animals has been described by Halmi et al., (2012). The study showed the hypoglycemic activity of $O$. ficus-indica cladodes among the norm glycemic rabbits and in case of hyperglycemia. Kaur et al. 
(2012) investigate the effect fruit juice of $O$. ficus-indica on some biochemical parameters, enzyme activities and lipid peroxidation in alloxan-induced diabetic rats. Treatment of the diabetic rats with single or repeated dose of cactus fruit juice could restore the changes of the above parameters to their normal levels. The same results were achieved by Hassan et al., (2014).

The active ingredient in Allium cepa is allyl propyl disulfide together with the phenolic compound Quercetin (Kumari et al., 1995). Ozougwu (2011) found that Allium cepa exhibited promising hypoglycaemic and hypolipidaemic activity in alloxan-induced diabetic rats. It's hypoglycaemic and hypolipidaemic effects could represent a protective mechanism against the development of hyperglycaemia and hyperlipidaemia characteristic of diabetes mellitus. The active ingredient allyl propyl disulfide in onions may have antidiabetic properties as reported by previous studies (Andallu et al., 2001). Sun-Ho Kim et al., (2011) found that the extract of onion skin may improve exaggerated postprandial spikes in blood glucose and glucose homeostasis, since it inhibits intestinal sucrose and thus delays carbohydrate absorption. They suggested that clinical trials are also needed.

Basak and Candan (2013) identified 29 compounds representing $99.18 \%$ of the total oil of Laurus nobilis. 1,8-cineole (68.82\%), 1-(S)- $\alpha$-pinene (6.94\%), and R-(+)- limonene (3.04\%) were determined to be the main components. The results of this study indicate that the essential oil and 1,8-cineole inhibit $\alpha$-glucosidase by competitive inhibition, but 1-(S)- $\alpha$-pinene and $\mathrm{R}-(+)-$ limonene are uncompetitive inhibitors. Since the results suggest that the essential oil obtained from laurel leaves and its main components inhibit $\alpha$-glucosidase, the whole oil or its main components could be effective in the treatment of diabetes by scavenging reactive oxygen species and inhibiting $\alpha$ glucosidase. However, the study suggested the need of in-vivo experiments to confirm the obtained results.

In conclusion, management of diabetes with minimized side effects is still complicated medical challenge. There is an increasing demand by patients to use the natural products with anti-diabetic activity, because both insulin and oral hypoglycemic drugs possess undesirable side effects (Kameswara, 2001). Local traditional knowledge and the practice of plant-based medicine are still widespread in Tabuk district in Saudi Arabia and traditional healers play an important role in primary health care. Conservation of plants is necessary as it ensures the availability of plants for traditional herbalists, traditional healers and herb sellers. One major advantage of traditional medicine is that, it is easy access to the plants, cheaper than orthodox medicine and the simplicity of preparing medicines from plants. The present results also that all the recorded species have a therapeutic effect on DM and the effective compounds differed from one species to the other. But there is no study on using a mixture of two or more plants to insure a complete remediation of the disease. However, the current study recommended with more studies on protocol using different regions for more plant species.

\section{Authors' contributions}

AF conducted the ethnobotanical survey and analyzed the field data. AF drafted the manuscript and $\mathrm{MM}$ conceptualized the study. MM reviewed the research proposal. Both authors participated in writing and giving feedback on the manuscript. All 
authors have read and approved the final manuscript.

\section{Acknowledgement}

The authors are highly thankful to traditional herbalists, traditional healers and rural dwellers for their co-operation and providing us with valuable information. We are also very much grateful to Prof. Dr. M. A. Elhaak, Faculty of Science, Tanta University, Tanta, Egypt for his valuable comments.

\section{References}

Al-Amin, Z.M., Thomson, M,, Al-Qattan, K.K., Peltonen-Shalaby, R., Ali, M. 2006. Anti-diabetic and hypolipidaemic properties of ginger (Zingiber officinale) in streptozotocin-induced diabetic rats. British J. Nutrition, 96: 660-666.

Al-Dhubiab, B.E. 2012. Pharmaceutical applications and phytochemical profile of Cinnamomum burmannii. Pharmacognosy Rev., 6: 125-131.

Andallu, B., Suryakantham, V,. Lakshmi, S.B. 2001. Effect of mulberry (Morms indica L) therapy on plasma and erythrocyte membrane lipids in patients with Type 2 diabetes. Clinica Chimica Acta, 314: 47-53.

Bahmani, M., Zargaran, A., Rafieian-Kopaei, M., Saki, K. 2014. Ethnobotanical study of medicinal plants used in the management of diabetes mellitus in the Urmia, Northwest Iran. Asian Pacific J. Trop. Med., 7: S348-S354

Basak, S., Candan, F. 2013. Effect of Laurus nobilis L. Essential Oil and its Main Components on $\alpha$-glucosidase and Reactive Oxygen Species Scavenging Activity. Iranian J. Pharma. Res., 12: 367-379.

Bharat, B.A., Anushree, K., SManoj, S.A., Shishir,

S. 2005.
Hytopharmaceuticals in Cancer Chemoprevention 2005, CRC Press LLC.

Bock, M., Derraik, G.B., Brennan, M.C., Biggs, J.B., Morgan, P.E., Hodgkinson, S.C., Hofman, P.L., Cutfield, W.S. 2013. Olive (Olea europaea L.) Leaf Polyphenols Improve Insulin Sensitivity in Middle-Aged Overweight Men: A Randomized, Placebo-Controlled, Crossover Trial, Volume 8 | Issue 3 | e57622

Collenette, S. 1999. Wildflowers of Saudi Arabia National Commission for Wild life Conservation and Development. (NCWCD) KSA.

El-Ghazali, G.E., Al-Khalifa, K.S., Saleem, G.A. 2006. Common wild plantsat Al-Rass province and its folkloric uses. 1st ed., Alrushd Publishing,Saudi Arabia, p. 13.

Fransworth, N.R., Soejarto, D.D. 1985. Potential consequences of plant extinction in the United States on the current and future availability of prescription drugs. Eco. Bot., 39: 231 -240 .

Halmi, S., Benlakssira, B,. Bechlarzi, K., Djerrou, Z., Djeaalab, H,. Riachi, F., HamdiPacha, Y. 2012. Antihyperglycemic activity of prickly pear (Opuntia ficus- indica) aqueous extract. Int. J. Med. Aromatic Plants, 2: 540-543.

Hasan, H.A., Rasheed Raauf, A.M., Abd Razik, B.M., Rasool Hassan, B.A. 2012. Pharmaceut Chemical Composition and Antimicrobial Activity of the Crude ExtractsIsolated from Zingiber Officinale by Different Solvents. Pharmaceutica Analytica Acta J., 3: 184.

Hassan, F., El-Razek, A., Hassan, A.A. 2012. Nutritional Value and Hypoglycemic Effect of Prickly Cactus Pear 
(Opuntia ficus-indica) Fruit Juice in Alloxan-Induced Diabetic Rats. Australian J. Basic and Appl.Sciences, 5: 356-377.

Jafri, S.A., Abass, S., Qasim, M. 2010. Hypoglycemic effect of ginger (Zingiber officinale) in alloxan induced diabetic rats (Rattus norvagicus). Pakistan Vet. J., 31: $160-162$.

Jose-Alberto, G.I., Nuria-Elizabeth, R., Ruben Francesco, G., Rosalia, R., Luis Medina, T., Veronica, C. 2009. Effect of air flow rate on the polyphenols content and antioxidant capacity of convective dried cactus pear cladodes (Opuntia ficus-indica). Int. J. Food Sci. Nutri., 60: 80-87.

Kaeidi, A.1., Esmaeili-Mahani, S., Sheibani, V., Abbasnejad, M., Rasoulian, B., Hajializadeh, Z., Afrazi, S. 2011. Olive (Olea europaea L.) leaf extract attenuates early diabetic neuropathic pain through prevention of high glucose-induced apoptosis: in vitro and in vivo studies. $J$. Ethnopharmacol., 136: 188-96.

Kameswara, R.A.O., Appa, B., CH, R.A.O., 2001. Hypoglycemic and antihyperglycemic activity of alternifolium (Wt.) Walp. Seed extracts in normal and diabetic rats. Phytomed., pp. 88-93.

Kaur, M., Kaur, A., Sharma, R. 2012. Pharmacological actions of Opuntia ficus indica: A Review J. Appl. Pharma. Sci., 02: 15-18.

Kumari, K., Mathew, B.C., Augusti, K.T. 1995. Anti-diabetic and hypolipidaemic effects of S - methyl cysteine sulfoxide isolated from Allium cepa Linn. Indian J. Biochem. Biophysics., 32: 49-54.

Mahluji, S., Attari, V.E., Mobasseri, M., Payahoo, L., Ostadrahimi, A., Golzari, S.E.J. 2013. Effects of ginger
(Zingiber officinale) on plasma glucose level, HbA1c and nsulin sensitivity in type 2 diabetic patients. Int. J. Food Sci. Nutri., 64: 682-686.

Maiti, R., Jana, D., Das, U.K., Ghosh, D. 2004. Antidiabetic effect of aqueous extract of seed of Tamarindus indica in streptozotocin-induced diabetic rats. J. Ethnopharmacol., 92: 85-91.

Malviya, N., Jain, S., Malviya, S. 2010. Antidiabetic potential of medicinal plants. Acta Poloniae Pharmaceutica, 67: 113-118.

Migahid, A.M. 1996. Flora of Saudi Arabia vol. 1, 2, 3. 1996, King Saud University, Riyadh, KSA.

Mitra, A. 2008. Some salient points in dietary and life-style survey of rural Bengal particularly tribal populace in relation to rural diabetes prevalence. Studies on Ethno-Medicine, 2: 51-56.

Ojewole, J.A.O. 2006. Analgesic, antiinflammatory and hypoglycaemic effects of ethanol extract of Zingiber officinale (Roscoe) rhizomes (Zingiberaceae) in mice and rats. Phytotherapy Res. J., 20: 764-772.

Ozougwu, J.C. 2011. Anti-diabetic effects of Allium cepa (onions) aqueous extracts on alloxan-induced diabetic Rattus novergicus. J. Med. Plants Res., 5(7): 1134-1139.

Patel, D.K., Kumar, R., Prasad, S.K., Hemalatha, S. 2011. Pedalium murex Linn (Pedaliaceae) fruits: a comparative antioxidant activity of its different fractions. Asian Pacific J. Trop. Biomed., 1: 395-400.

Polansky, M.M., Anderson, R.A. 2007. Cinnamon extract and polyphenols affect the expression of tristetraprolin, insulin receptor, and glucose transporter 4 in mouse 3T3-L1 adipocytes. Archives of Biochemistry and Biophysics, 22: 459:214.

Ponnusamy, S., Ravindran, R,. Zinjarde, S., 
Bhargava, S., Ravi Kumar, A. 2011. Evaluation of Traditional Indian Antidiabetic Medicinal Plants for Human Pancreatic Amylase Inhibitory Effect In Vitro. EvidenceBased Complementary and Alternative Medicine, Volume 2011, Article ID 515647, 10 pages.

Rashmi, Y., Rahul, K. 2011. A study of phytochemical constituents and pharmacological actions of Trigonella foenum-graecum: A review. Int. J. Pharm. Technol., 3: 1022-1028.

Sawant, R.S., Godghate, A.G. 2013. Qualitative phytochemical screening of rhizomes of Curcuma longa Linn. Int. J. Sci. Environ. Technol., 2: $634-$ 641.

Sharma, S., Kulkarni, S.K., Chopra, K. 2006. Curcumin, the active principle of turmeric (Curcuma longa), ameliorates diabetic nephropathy in rats. Clin. Experimental Pharmacol. Physiol., 33: 940-945.

Soejarto, D.D., Fransworth, N.R. 1989. Tropical rain forests: Potential source of new drugs? Perspectives in Biol. Med., 32: 244- 256.

Sun-Ho, K., Sung-Hoon, J., Young-In, K., Jae-Kwan, H. 2011. Effects of Onion $\begin{array}{lll}\text { (Allium cepa } & \text { L.) } \quad \text { Extract }\end{array}$
Administration on Intestinal $\alpha$ Glucosidases Activities and Spikes in Postprandial Blood Glucose Levels in SD Rats Model. Int. J. Mol. Sci., 12: 3757-3769.

Tang, M., Larson-Meyer, D.E., Liebman, M. 2008. Effect of cinnamon and turmeric on urinary oxalate excretion, plasma lipids, and plasma glucose in healthy subjects. American J. Clin. Nutri., 87: 1262-1267.

Tjandrawinata, R.R., Sinambela, J.M., Mayasari, O., Dwi, D.D., Puspasari, M. 2011. Herbal extract as sensitivity enhancer toward insulin and antidiabetes.US patent number 2011, 2011/0177177.

Wickenberg, J., Ingemansson, S.L., Hlebowicz, J. 2010. Effects of Curcuma longa (turmeric) on postprandial plasma glucose and insulin in healthy subjects. Nutrition J., 9: 43-47.

World Health Organisation (WHO). 1976. Afro Tech. Rep. Series 1. Brazaville, 3-4.

Zimmet, P.Z., Magliano, D.J., Herman, W.H., Shaw, J.E. 2014. Diabetes: a 21 st century challenge. The Lancet \& Diabetes Endocrinol., 2: 56-64.

\section{How to cite this article:}

Amal, M. Fakhry and Masarrat, M.M. Migahid. 2016. Ethnobotanical Survey of Plants Used in the Treatment of Diabetes Mellitus in Tabuk Region, Saudi Arabia. Int.J.Curr.Microbiol.App.Sci. 5(6): 258-270. doi: http://dx.doi.org/10.20546/ijcmas.2016.506.029 